\title{
Regulation Improvement of Right to Education Policy for Street Children in Padang City
}

\author{
Aurora Virgonia Niswar, 1 \\ Rozidateno Putri Hanida, ${ }^{2}$ \\ Roni Ekha Putera ${ }^{3}$ \\ 1,2,3 Department of Public Administration, \\ Faculty of Social and Political Science, \\ Universitas Andalas, Padang - Indonesia
}

Corresponding Author: Roni Ekha Putera, email: roniekhaputera@soc.unand.ac.id, Kampus Unand Limau Manis, Pauh, Padang, Sumatera Barat 25175

\begin{abstract}
The fulfillment policy of the right to education for street children has been included in some policies in Padang City. However, it still hasn't been able to solve the problem. Hence, policy improvements are as impressive as research topics. The propose of this research is to describe and analyze the implementation process of education rights fulfillment for street children in Padang city. This research was conducted using qualitative research methods and descriptive design by employing library research and field research. The data were collected through interviews and documentation. The results of this research show that the policy needs improvement because there have been obstacles during the implementation of the policy, which make the policy not function optimally.
\end{abstract} $\begin{array}{ll}\text { Keywords: } & \begin{array}{l}\text { education rights fulfillment; street children; } \\ \text { policy improvement }\end{array}\end{array}$

Abstrak: Kebijakan pemenuhan hak pendidikan bagi anak jalanan telah dimuat dalam beberapa produk kebijakan yang ada di Kota Padang. Namun hal ini masih belum menemukan titik terang dalam mengatasi masalah pendidikan anak jalanan. Sehingga kajian mengenai perbaikan peraturan menjadi menarik untuk ditelaah lebih lanjut. Tujuan penelitian ini untuk mendeskripsikan dan menganalisis implementasi kebijakan pemenuhan hak pendidikan yang telah ada. Metode yang digunakan dalam penelitian ini adalah deskriptif kualitatif dengan teknik pengumpulan data melalui wawancara, observasi, dan dokumentasi. Hasil penelitian menunjukkan bahwa kebijakan pemenuhan hak pendidikan terhadap anak jalanan di Kota Padang membutuhkan perbaikan peraturan sebab terdapat beberapa masalah yang dihadapi selama proses pelaksaan kebijakan tersebut, sehingga membuat kebijakan ini tidak mampu berjalan secara optimal.

Kata Kunci: anakjalanan; pemenuhan hakpendidikan; perbaikan peraturan 


\section{A. Introduction}

The fulfillment of the right to children's education is one of the indicators of whether a country falls into the category of a developed, or developing country. Education is also interpreted as a part of both public goods and not public goods. In this context, education can be a publicly-owned service item (public), where every community has the same right to get education and teaching as outlined in the mandate of law. ${ }^{1}$

The state has guaranteed the fulfillment of children's right to education through a series of the legal constitution that has been previously issued by the government, central government, and regional governments. In the amendment to the 1945 Constitution in 2000 article 28c verse (1) it is explained that everyone has the right to develop themselves through fulfilling their basic needs, right to education, and to benefit from science and technology, arts and culture, to improve their quality of life and for the welfare as human".

Besides, law No. 23 of 2002 concerning Child Protection Article 19 verse (1) affirms that every child has the right to education and teaching in the context of their personal development and level of intelligence according to their interests and talents. ${ }^{2}$ Besides, the fulfillment of children's right to education is also strengthened through a ministerial regulation, namely Minister of Women's Empowerment and Child Protection Regulation No. 5 of 2011 concerning Policies on Fulfilling Children's Right to Education. ${ }^{3}$

However, it seems that those policies have not been able to guarantee the fulfillment of children's right to education. The increasing dropout rates can be an indicator of the difficulty of fulfilling the right to education. This is evidenced by an increase in dropout rates that occur in many areas, one of which is the City of Padang. According to the Document Center for Education and Culture Data and Statistics In the 2017/2018 Academic Year, Padang City was ranked first in West Sumatra Province with the highest number of

\footnotetext{
${ }^{1}$ Arifin Suking Arwildayanto and Warni Tune Sumar, Analisis Kebijakan Pendidikan: Kajian Teoretis, Eksploratif, dan Aplikatif (Bandung: Cendikia Press, 2018); Etsuko Sugawara and Hiroshi Nikaido, "Summary for Policymakers," in Climate Change 2013 - The Physical Science Basis, ed. Intergovernmental Panel on Climate Change, 1st ed., vol. 58 (Cambridge: Cambridge University Press, 2014), 1-30, https://doi.org/10.1017/CB09781107415324.004.

2Law No. 23 of 2002 Concerning Child Protection, Article 19 Verse 1.

${ }^{3}$ Minister of Women's Empowerment and Child Protection Regulation No. 5 of 2011 Concerning Policies on Fulfilling Children's Education Rights.
} 
dropouts, with a total of 622 students. This phenomenon can also be affected by other factors, as Jamaluddin et al. assert that the lack of knowledge about the significance of education in their life is also one of the reasons for the lack of awareness to attain a decent education. One way to resolve this problem is to approach them personally. 4

The phenomenon of dropping out of school will have an impact on the environment. Tamara's research showed the same thing, that another factor often the one which is the cause of the problems faced by children, is the environmental factor. 5 As written by Gunawan in Muamalah's research which said that the problem of dropping out of school, especially at the lower level of education, then not working and earning a steady income, can be a burden of the community and even often disturbs the peace of the community, the problem of dropping out of school can cause disturbances in society in the form of delinquency which is contrary to positive social norms. ${ }^{6}$ One form of public peace can be in the form of the presence of street children. ${ }^{7}$

Street children are children who, most of the time, are on the streets or public places with a minimum of four hours a day within one month. ${ }^{8}$ These two things are closely related to where children who do not have activities (studying/schooling) will tend to spend their time outside the home or on the streets. In addition to dropping out of school, the current urbanization that is happening in Indonesia also causes an increase in the number of street children that occur every year, so this requires comprehensive treatment. ${ }^{9}$

${ }^{4}$ Jamiludin Jamiludin et al., "Street Children's Problem in Getting Education: Economic and Parental Factors," Mediterranean Journal of Social Sciences 9, no. 1 (2018): 103-8, https://doi.org/ 10.2478/mjss-2018-0010.

${ }^{5}$ Ameylia Firza Tamara, "The Impact of Save Street Child Jogja Community on Children in Street Situation (CSS) in Daerah Istimewa Yogyakarta," International Journal of Management and Applied Science 3, no. 4 (2017): 59-62, http://iraj.in.

${ }^{6}$ Bad'ul Muamalah and Ratnasari Diah Utami, "Studi Analisis Penanganan Anak Putus Sekolah di Desa Ngepanrejo Kecamatan Bandongan Kabupaten Magelang” (Universitas Muhammadiyah Surakarta, 2017).

${ }^{7}$ Muamalah and Utami. Article 1.

8Padang City Regulation Number 2 of 2012 concerning Child Development and Protection,

${ }^{9}$ Herlina Astri, "Kehidupan Anak Jalanan Di Indonesia: Faktor Penyebab, Tatanan Hidup Dan Kerentanan Berperilaku Menyimpang," Aspirasi:Jurnal Masalah-Masalah Sosial 5, no. 2 (2014): 14555, https://doi.org/10.46807/aspirasi.v5i2.454. 
Street children are the most vulnerable groups in the effort to fulfill the right education. Similarly, IEC and Thompson in Kisirkoi \& Mse say that it is difficult, for street children to enroll in learning centers and schools. ${ }^{10}$ Moreover, Alam and Wajidi found that they (street children) Complained that they were denied admission in public and private schools. ${ }^{11}$ The children protested that they were treated in the society as rejected a lot. Consequently, a specific approach is needed to fulfill their right to education so that it runs well and minimizes the discriminatory actions and the violation of the law.

Deawinadry and Hashim, in their research, mention that the state, local governments, communities, families, and parents are obliged to provide protection and ensure the fulfillment of child rights based on the duties and responsibilities. ${ }^{12}$ The problem of education and street children has been a concern of Padang City government for a long time, and this is indicated by the policies issued by the local government, namely the Padang City Regional Regulation No. 2 of 2012 concerning Child Development and Protection. The body of this policy states that the local government is obliged to organize social welfare in the form of educational services for street children? This education policy is made to solve problems faced by the people. To solve the problems needs the support and participation of people. ${ }^{13}$

To reinforce the policy of fulfilling the right to education of street children in Padang City, the government issued Padang Mayor Regulation No. 41 of 2017 concerning Procedures for the Coaching of Street Children. However, the existing policies have not been able to solve the problem of street children's education. This is indicated by the continued increase in the number of street children who have not received education in the last few years. Here is a diagram of the increase in the number of street children who do not get an education (Figure 1).

${ }^{10}$ Florence Kanorio Kisirkoi and Godfrey Shed Mse, "Education Access and Retention for Street Children: Perspectives from Kenya," Journal of Education and Practice 7, no. 2 (2016): 88-94.

${ }^{11}$ Sarah Alam and M. Abuzar Wajidi, "Refining the Street Children with Education," IOSR Journal of Research \& Method in Education (IOSRJRME) 4, no. 3 (2014): 54-57, https://doi.org/ 10.9790/7388-04335457.

${ }^{12}$ Deawinadry Deawinadry and Mochamad Wachid Hasyim, "Penerapan Peraturan Daerah Kota Kediri Nomor 4 Tahun 2013 tentang Pembinaan Anak Jalanan, Gelandangan dan Pengemis terhadap Perlindungan Anak Jalanan," Diversi: Jurnal Hukum 3, no. 2 (June 3, 2018): 157-76, https://doi.org/10.32503/diversi.v3i2.161.

${ }^{13}$ Ali Imron, Kebijaksanaan Pendidikan di Indonesia (Jakarta: Bumi Aksara, 1996). 


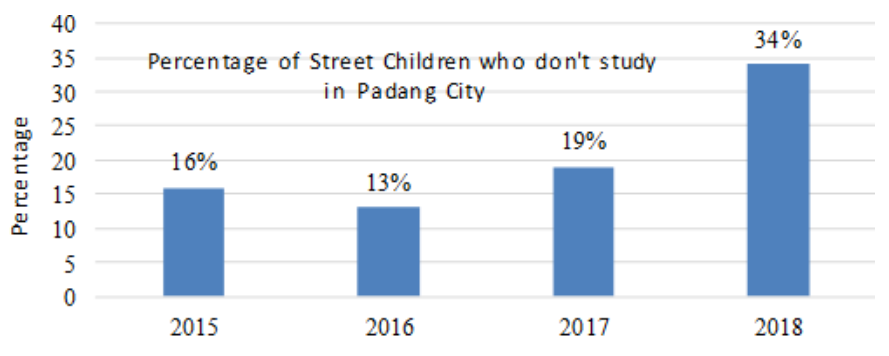

Figure 1.

Percentage of street children who do not attend school in Padang City Source: Researcher Processed in 2019 from the Padang City Social Service UPPKSA

Document 2019

It appears that there is an increase in the percentage of street children who do not get an education. It means the policy of fulfilling the right to education in Padang City has not run optimally. Aulia, in his research, explains that so far the attention given to street children has not been sufficient since the government has not empowered street children. Many children still wander along the streets. ${ }^{14}$ Therefore, a study on the implementation of policies on fulfilling the right to education of street children in Padang is needed, so that the findings obtained can be used as a reference for the improvement of regulations on the fulfillment of the right to education for street children in Padang in the future.

\section{B. The Implementation of Right to Education Fulfillment Policies for Street Children in Padang City}

Implementation becomes an essential stage in the policy process to achieve policy objectives. Policy implementation can be seen by comparing the policy objectives issued by the government (goals and benefits) to the beneficiaries of the policy, which in this case is the community. This is to say that if the contents of the policy issued can provide excellent benefits for the

\footnotetext{
${ }^{14}$ Annisa Rizky Aulia, "Pemberdayaan Anak Jalanan Melalui Program Pendidikan Kesetaraan di Rumah Singgah Anak Mandiri Yogyakarta," E-Diklus Jurnal Elektronik Mahasiswa S1 Program Studi Pendidikan Luar Sekolah 7, no. 3 (2018): 329-48.
} 
community, the policy is considered auspicious. Conversely, if the community considers the program issued by the government is not sufficient, the policy is considered a failure. On the other hand, Keban states that policy implementation is a stage where policies that have been adopted are implemented by specific administrative units by mobilizing existing funds and resources..$^{15}$

To analyze the implementation of the fulfillment policy of street children's right to education in Padang City, the theory used as a reference is the theory of policy implementation stated by Mazmanian and Sabatier. Mazmanian and Sabatier argue that the crucial role of implementation analysis is to identify the factors which affect the achievement of the objectives throughout this entire process ${ }^{16}$. Mazmanian and Sabatier describe the factors that influence the implementation of the policy into three major parts, namely tractability of the problem being addressed by the statute (the ability to control easily), the ability of the problem to favorably structure the implementation process (the ability of the policy to structure the implementation process) and the net effect of a variety of "political" variables on the balance of support for statutory objectives (variables outside the policy that affect the implementation process) and the stages (or dependent variables) in the implementation process (referred to as independent variables, and the implementation stages are referred to as dependent variables). ${ }^{17}$

This research will be analyzed using the theory because the theoretical model fits the characteristics of the fulfillment policy of the street children's right to education, which is a top-down policy. The influence of the four factors on the implementation of the street children's right to education policy fulfillment will be described as follows:

\section{The Feasibility of Controlling a Problem}

In implementing the street children's right to education policy fulfillment, the City Government of Padang, together with the Padang City Social Service,

\footnotetext{
15Yeremias T. Keban, Enam Dimensi Strategis Administrasi Publik: Konsep, Teori dan Isu (Yogyakarta: Gava Media, 2018).

16Paul Sabatier and Daniel Mazmanian, "The Implementation of Public Policy; A Framework of Analysis," Policy Studies Journal 8, no. 4 (1980): 538-60, https://doi.org/10.1111/j.15410072.1980.tb01266.x.

${ }^{17}$ Sabatier and Mazmanian.
} 
the Padang City Education Office, and the Padang City SatPol PP, are the primary activators. Each SKPD involved has its primary duty and function. The technical implementation of this policy is carried out based on each primary function of each SKPD involved and refers to the guidelines for the handling of street children issued by the Padang City Social Service based on the results of the agreement $(\mathrm{MoU})$ in the context of handling street children through an integrated coaching pattern promoted by the Social Service Kota Padang as the leading sector.

The technical implementation of this policy will be carried out first by the PP Padang, Padang Police Unit as the authorized party to screen street children. The street children who have been saved will be handed over to the Padang City Social Service Agency. After the street children are handed over to the Social Service Agency, the Agency will conduct an assessment and data collection on the street children. Then the street children will be validated their feelings or desires whether they have the desire to be able to get their education back or not. If the street child expresses his desire to be re-educated, the Social Service Agency will coordinate with the Padang City Education Office to be further facilitated by the education office. This is following their duties, as stated in the guidelines for handling street children. However, getting to this stage is not easy.

This research finds that the problem of controlling the street children are also influenced by the diversity of the behavior of the target group. This diversity is influenced by several factors, i.e. internal and external factors. Internal factors can be interpreted in their inclination, while external factors can be interpreted as environmental influences and knowledge that make them respond differently to policy. In the implementation of the policy of fulfilling the right to education to street children in Padang, it can be seen that the tendency that occurs among the behavior of these target groups is the refusal of them to be facilitated their education.

Apart from the diversity of the target group's behavior towards this policy, documenting the data well also has an impact on whether or not this problem is easy to control. This relates to the percentage of the target group to the population, where it will be a difficult problem to control when the implementor does not know and cannot map which target group and which population. Based on the findings, it is known that the Padang City Social 
Service Agency itself does not have well-documented data, so they also do not know how to map the target groups for this policy,

Besides, the behavioral change targeted by the policy will also affect the feasibility of controlling the problem. In the context of implementing the policy of fulfilling the right to education to street children, the expected behavior change is related to their awareness to be aware of their education. But as stated by Mazmanian and Sabatier in Subarsono that a program that is aimed at providing knowledge or is cognitive will be relatively easier to implement compared with programs aimed at changing people's behavior ${ }^{18}$. in term of the policy of fulfilling the right to education to street children, it can be concluded that the implementation of the policy of fulfilling the right to education to street children is a difficult problem to control.

\section{The Capability of a Policy to Structure the Implementation Process}

Every policy must be able to structure the implementation process, which can be seen through several points that are considered essential and able to explain the purpose of this variable, namely by setting out the formal goals that will be achieved clearly (clarity of policy content), the adequacy of the causal theory, accurate allocation of finance or financial resources for policies, the integrated hierarchy within and between implementing agencies, clarity, and consistency of rules that exist in implementing agencies, the level of commitment of the apparatus to policy objectives, and by providing access or opportunities to participate for external or private parties or non-governmental organizations in the implementation process.

Regarding the ability of this policy in describing the clarity of the contents of the policy objectives, it is found that the clarity of the contents of the policy of fulfilling the right to education to street children in Padang is still not optimal. This is because the policy of fulfilling the right is not a policy promulgated with a separate nomenclature, namely 'the policy of fulfilling the right to education to street children,' but contained in the body of other policies and with other nomenclature. Based on the results of the interviews with informants, it is known that several implementors do not understand this policy and it influences the implementation of the policy of fulfilling the right to education for street children.

\footnotetext{
${ }^{18}$ A. G. Subarsono, Analisis Kebijakan Publik (Yogyakarta: Pustaka Pelajar, 2006).
} 
In general, the policy of fulfilling the right to education of street children in Padang City has had a sufficiently causal theory. It can be seen from Padang Mayor Regulation No. 41 of 2017 concerning the Procedures for the Coaching of Street Children. However, when viewed further, the regulations which are owned by Padang City dealing with the fulfillment of the right to education for street children are sill minimal, because they lack clarity of the fulfillment policy.

From the budget side, the Padang City government has recorded a reasonably good budget. The fulfillment policy is budgeted in Padang City Regional Budget in the field of education. According to Padang City Social Service Agency's Work Plan of 2018, the budgeted funds increased in 2018 to Two hundred thirty billion Rupiah, which previously amounted to 209 Billion Rupiah in 2017. This fund will be allocated for all types of educational needs, including for education funds that can be accessed and enjoyed by street children, namely equality/package of education. Padang City Education Office is one of the SKPDs that receives funding from the Padang City Regional Budget. The equality of education program is also budgeted based on the Padang City Education Office Work Plan of 2016 until 2018. Nevertheless, the budget allocated by the education office is still insufficient; this is evidenced by the finding that the amount of the budget in the implementation of equality of education during the last three years tends to be less than the number of funds budgeted in the budget plan. Furthermore, PKBM itself, as an operational institution that runs equality of education program, also feels the impact and is experiencing financial difficulties due to the uncertainty of assistance to be channeled through the education office.

Meanwhile, Padang City Social Service Agency itself does not have a budget specifically for the fulfillment of the rights to education of street children. However, the budget for this activity is combined with several other activities related to street children, the budget of the overall street children handling program. To conclude, in terms of the allocation of finance/financial resources, it is not running optimally.

Concerning the ability of policies to structure the implementation process, a policy should be able to explain and describe the integration of hierarchies within and between the implementation agencies. Hierarchical cohesiveness can be seen through the quality of coordination carried out by the implementing agencies. Regarding the implementation of the policy of fulfilling the 
right to education of street children in Padang City, it can be concluded that the integrated hierarchy of coordination that exists is still not optimal. In general, this is caused by the weakness of the policy in outlining and explaining the contents of the policy, so that it will have an impact not only on one aspect. Like the integration of this hierarchy, weak coordination is caused by unclear rules,

Another factor also influencing the policy of the implementation process to which extent the opportunity of participation is opened to private and nongovernmental organizations. It appears that the Padang City government has opened the opportunity for private sectors and non-governmental organizations. This is evidenced by the involvement of PKBM (Community of Learning Centers). However, access to participation from the PKBM as an outsider does not have legal certainty. So, PKBM can reject street children who want to attend education arbitrarily. In this case, PKBM cannot be blamed ultimately.

\section{Policy Environment}

In implementing a policy, the environment outside of the policy itself also has an effect that is no less influential on the achievement of the goals set by the policy. The environment referred to in this variable is related to the socioeconomic and technological conditions, public support, attitudes of the voting group, support from superior officials, as well as the level of commitment and skills of the apparatus and implementor.

Referring to socio-economic and technological conditions, in terms of implementing the policy of fulfilling the right to education of street children in Padang City, it is found that street children tend to reject this policy due to weak economic conditions. They are forced to remain on the road than following education fulfillment programs. Meanwhile, when viewed from social conditions, it is known that social problems related to street children have not become a concern of the government itself. This is reflected in the actions taken by Padang City Social Service and its Education Office.

Based on the results of the interview conducted with several informants at the social and education offices, it shows that there are still many problems that are more urgent than the problems of street children's education. So that the trend that occurs is an attitude that "half-measures" in solving this problem, this is also felt by the public, and it appears that public support in this policy is still somewhat "between there and nothing" because there are still many people who do not care about this problem, including the voter group. 
Voter groups are defined as groups that can provide intervention to decisions made by the implementing body. In this study, Padang City DPRD was made part of the voter group because it was relevant to the meaning of the voter group itself. Based on the finding, Padang City DPRD, as the party that has the authority to make draft policies or regional regulations, does not yet have an intention to formulate more specific policies related to fulfilling the right to education of street children. It can be said that the role of the voting group has not been able to have a significant impact on the successful implementation of the policy of fulfilling the right to education of street children in Padang City.

The implementation of the policy of fulfilling the right to education of street children also needs the support of officials. The size of the support can have a significant impact on the policy implementation process. This form of support can be done in several ways. In Padang City, the support has been provided support materially, in the form of a budget and non-materially, in the form of motivation. However, the support of the supervisor of the Padang City Education Office is considered not optimal, specifically on material support. This is evidenced by the large amount of the budget which was budgeted by his subordinates for the implementation of equality/package of education is not necessarily approved as the amount that has been designed. What happens is that the approved funds are always below the targeted budget prepared by his subordinates.

The things that have been explained before will ultimately lead to the commitment of the policy implementers. When viewed and considered further, every point of the problem in this policy environment variable, which starts from the socio-economic and technological conditions, public support, the attitude of the voting group, to the support of superior officials will be closely related to the commitment of the policy implementers. However, it cannot be denied that other things become obstacles in the process of implementing the policy of fulfilling the right to education of street children in Padang City, as explained in the previous sub-sections.

\section{Steps in the Implementation Process}

In this variable, there are some stages, which can be called an endpoint or a dependent variable. Each of these stages is also an input for success in the other stages. The stages of the implementation process in question are the policy output from the implementing agency, the target group's compliance 
with the policy output, the real impact of the policy, the perceived impact of the policy output, and ultimately lead to the improvement of regulations. Policy outputs from the implementing agency, namely Padang City Social Service Agency, and Padang City Education Office make some efforts so that the fulfillment of the right to education of street children can be carried out properly.

Table 1.

Data on the Condition of Street Children in 2015-2018

\begin{tabular}{lcccc}
\hline \multirow{2}{*}{ Criteria } & \multicolumn{3}{c}{ Year } \\
\cline { 2 - 5 } & $\mathbf{2 0 1 5}$ & $\mathbf{2 0 1 6}$ & $\mathbf{2 0 1 7}$ & $\mathbf{2 0 1 8}$ \\
\hline Total Number of Street Children & 29 & 45 & 78 & 117 \\
\hline Number of School-age Street Children & 12 & 15 & 36 & 55 \\
\hline $\begin{array}{l}\text { Number of Street Children Who Get } \\
\text { Education }\end{array}$ & 2 & 2 & 7 & 19 \\
\hline $\begin{array}{l}\text { Number of Street Children Who Have No } \\
\text { Education / Drop Out }\end{array}$ & 10 & 13 & 9 & 36 \\
\hline
\end{tabular}

Source: Processed Researchers from the Padang City Social Service in 2019

Based on interviews with some informants, it can be concluded that the output of the policy of fulfilling the right of education to street children is the availability of street children to pursue education without being discriminated against or made difficult to obtain by cooperating with the education office. Nevertheless, what happens is that the target group's compliance with policy output is not in line with the policy output itself. This is indicated by the refusal of street children as the target group to be facilitated their education.

The rejection occurs due to inherent factors in the target group itself. Besides whether or not there is a sanction in policy will also have an impact on the target group's compliance with the policy. In the policy of fulfilling the right to education of street children in Padang City, there are no sanctions for violations committed by the target groups if they are not cooperative with the implementation apparatus. Such things like this will impact the alignment of the real impact of a policy with the impact of perceived policies.

After all the stages of the implementation process have been studied more deeply, then the end of this long process is to improve the regulations, as stated by Mazmanian and Sabatier. In implementing the policy of fulfilling the right to education of street children, it can be seen that several aspects need to be addressed in the future. 
Several informants suggest the improvement may be done by enacting the policy of fulfilling the right to education of street children to become a unified product of a stand-alone policy, not a policy that is within the body of another policy. This step needs to be taken due to the lack of understanding of the implementors of this policy. By formatting it into a stand-alone policy, it is expected to be able to provide explicit content and consistency of strong objectives for the implementor and the target group.

\section{Conclusion}

In general, the implementation of the policy to fulfill the right to education of street children in Padang City had not yet run optimally. This is indicated by several obstacles that were discovered when this policy was implemented-the technical difficulties faced by the implementors such as the diversity of the behavior of the target group that was difficult to capture and control, unorganized and inadequate data, and the difficulty in changing the behavior of the target group.

Besides, the clarity of the contents of the policy which was still blurred because this policy was in the body of other policies so that it made it difficult for the implementors to understand the contents of the policy itself. The lack of understanding of the implementors in translating the policy also had an impact on the lack of commitment and coordination between institutions, which should have been done much more optimally. Therefore, the policy to fulfill the right to education of street children requires the improvement of regulations so that detailed policies are created so that they do not cause multiple interpretations.

The improvement of the regulation may be in the form of a whole separate regulation with the nomenclature of the policy 'fulfillment of the right to education of street children,' with the hope that when this policy has become independent, it can become a more detailed policy and easily understood by all circles, both from the perspective of the implementors, target groups, and ordinary people. In addition to drafting and issuing separate regulations, improvement steps can be in the form of the issuance of Regional Action Plans related to the fulfillment of the street children's right to education, so that everything related to the implementation of this policy can run optimally. [s] 


\section{References}

Alam, Sarah, and M. Abuzar Wajidi. "Refining the Street Children with Education." IOSR Journal of Research \& Method in Education (IOSRJRME) 4, no. 3 (2014): 54-57. https://doi.org/10.9790/7388-04335457.

Arwildayanto, Arifin Suking, and Warni Tune Sumar. Analisis Kebijakan Pendidikan: Kajian Teoretis, Eksploratif, dan Aplikatif. Bandung: Cendikia Press, 2018.

Astri, Herlina. "Kehidupan Anak Jalanan di Indonesia: Faktor Penyebab, Tatanan Hidup dan Kerentanan Berperilaku Menyimpang." Aspirasi: Jurnal MasalahMasalah Sosial 5, no. 2 (2014): 145-55. https://doi.org/10.46807/ aspirasi.v5i2.454.

Aulia, Annisa Rizky. "Pemberdayaan Anak Jalanan Melalui Program Pendidikan Kesetaraan di Rumah Singgah Anak Mandiri Yogyakarta." E-Diklus Jurnal Elektronik Mahasiswa S1 Program Studi Pendidikan Luar Sekolah 7, no. 3 (2018): 329-48.

Deawinadry, Deawinadry, and Mochamad Wachid Hasyim. "Penerapan Peraturan Daerah Kota Kediri Nomor 4 Tahun 2013 tentang Pembinaan Anak Jalanan, Gelandangan dan Pengemis Terhadap Perlindungan Anak Jalanan." Diversi: Jurnal Hukum 3, no. 2 (June 3, 2018): 157-76. https://doi.org/10.32503/ diversi.v3i2.161.

Imron, Ali. Kebijaksanaan Pendidikan Di Indonesia. Jakarta: Bumi Aksara, 1996.

Jamiludin, Jamiludin, Darnawati Darnawati, Waode Ade Sarasmita Uke, and Irawaty Irawaty. "Street Children's Problem in Getting Education: Economic and Parental Factors." Mediterranean Journal of Social Sciences 9, no. 1 (2018): 103-8. https://doi.org/10.2478/mjss-2018-0010.

Keban, Yeremias T. Enam Dimensi Strategis Administrasi Publik: Konsep, Teori Dan Isu. Yogyakarta: Gava Media, 2018.

Kisirkoi, Florence Kanorio, and Godfrey Shed Mse. "Education Access and Retention for Street Children: Perspectives from Kenya." Journal of Education and Practice 7, no. 2 (2016): 88-94.

Law No. 23 of 2002 concerning Child Protection.

Minister of Women's Empowerment and Child Protection Regulation No. 5 of 2011 concerning Policies on Fulfilling Children's Education Rights (2011).

Muamalah, Bad'ul, and Ratnasari Diah Utami. "Studi Analisis Penanganan Anak Putus Sekolah di Desa Ngepanrejo Kecamatan Bandongan Kabupaten Magelang." Universitas Muhammadiyah Surakarta, 2017. 
Padang City Regulation Number 2 of 2012 concerning Child Development and Protection.

Sabatier, Paul, and Daniel Mazmanian. "The Implementation of Public Policy; A Framework of Analysis." Policy Studies Journal 8, no. 4 (1980): 538-60. https://doi.org/10.1111/j.1541-0072.1980.tb01266.x.

Subarsono, A. G. Analisis Kebijakan Publik. Yogyakarta: Pustaka Pelajar, 2006.

Sugawara, Etsuko, and Hiroshi Nikaido. "Summary for Policymakers." In Climate Change 2013 - The Physical Science Basis, edited by Intergovernmental Panel on Climate Change, 1st ed., 58:1-30. Cambridge: Cambridge University Press, 2014. https://doi.org/10.1017/CB09781107415324.004.

Tamara, Ameylia Firza. "The Impact of Save Street Child Jogja Community on Children in Street Situation (CSS) in Daerah Istimewa Yogyakarta." International Journal of Management and Applied Science 3, no. 4 (2017): 59-62. http://iraj.in. 
Aurora Virgonia Niswar, Rozidateno Putri Hanida, Roni Ekha Putera

This page intentionally left blank. 
STACK :

/ GpPBeg1

-dictionarytrue

false 